\title{
広帯域ペン書オシログラプ
}

\author{
渡 部 慶 二・中津山幹男 \\ 山形大学工学部 米沢市城南 4 丁目 \\ (昭和 45 年 7 月 1 日 受付)
}

\section{Wideband Pen-Writing Oscillograph}

\author{
Keiji Watanabe and Mikio Nakatsuyama \\ (Faculty of Engineering, Yamagata University, Yonezawa) \\ (Received July 1, 1970)
}

\begin{abstract}
Frequency range of a pen-writing oscillograph is limited to be from DC to about $80 \mathrm{~Hz}$ because of the response of the galvanometer. If the high frequency signal is known to be periodic, it can be sampled and its frequency can be converted to a low frequency preserving its waveform. Thus the input signal can be recorded by a pen-writing oscillograph. The input waveform is necessary to be continuously sampled for a long time in the pen-writing oscillograph. In a sampling oscilloscope, however, the sampling operation is not continuous, because each sampling pulse is taken at a time progressively delayed with respect to some reference point in the input waveform and the delay time is not infinite.

In this paper, a new sampling technique for a pen-writing oscillograph is discussed. In this technique, sampling pulses are periodically taken. The frequency of the output signal after sampling is equal to the difference between $P \cdot F_{s}$ and the frequency of the input signal. $F_{s}$ is the sampling frequency and $P$ is a positive integer. The input waveform can be continuously sampled for a long time. However, the frequency drift of the output signal increases as the frequency of the output becomes lower.

In this paper, this new sampling technique is applied to a chopper amplifier and a frequency control system is contrived in order to compensate the frequency drift.

By the pen-writing oscillograph with this chopper amplifier, it is possible to record from DC to periodic signals of high frequency.

\section{1. まえがき}

ペン書オシログラフは，信号を直視できることと， 安価に記録に残すことができひびょうに便利であり， 直流から比較的低周波信号の測定，記録などに広く用 いられている. ペン書オシログラフを広帯域化する方 法にガルバノメータなどのペン駆動部の高速化がある. しかし、ペン駆動部は機械的な制約を受け，高速化す ることは一般に困難である.

本論文では, 回路的手法によるペン書オシログラフ の広帯域化を計った。すなわち, 周期的信号を低周波

$\dagger$ 電気関係学会東北支部連合大会で発表 $($ 昭 $44 \cdot 10)$

に周波数変換（以下低周波変換という）し，ペン書さ せることである.

ところで, 従来のサンプリング方式や他の低周波変 換方法を直接ペン書オシログラフに適用することは, 以下に述べる理由から困難である. サンプリング・オ シロスコープで用いられる従来のサンプリング・パル ス遅延方式(1) 3)では，波形を連続的にサンプリングす ることがむずかしく，また同期操作が必要であり，ぺ ン書させながら調整しなければならず好ましくない。 さらに，2つの周波数のらなりを用いる低周波変換方 法は, 入力波形の再現ができずペン書オシログラフに は不適当である.
\end{abstract}


本論文では，まず新しいサンプリング・パルス遅延 方式にういて述べ，つぎに，これを用いてペン書オシ ログラフを広帯域化する回路構成について述べた．本 論文のサンプリング・パルス遅延方式には，入力周波 数と一定の差をもつ繰返し周波数のパルスで入 カ信号をサンプリングするため, サンプリング ・パルスが自動的に遅延し連続的に低周波変換 できただちにペン書できるところに特徴があ る.さらに, この低周波変換方法は, チョッパ 増幅器に容易に適用でき，ペン書オシログラフ などの広帯域化にはひじょうに有効な方法であ る.上記の低周波変換機能をそな光たチョッパ 増幅器を試作し; ペン書オシログラフに用いた ところ，所望の広帯域特性が得られた。

このサンプリング方式では，入力信号の周波数変動 や，サンプリング周波数に存在する周波数ドリフトに よって出力周波数のドリフトが生じる. 出力周波数の ドリフトは広帯域化の妨げとなるので，これを低減す るための周波数制御系についても考察した.

\section{2. ペン書オシログラフの広帯域化}

\section{$2 \cdot 1$ サンプリングによる低周波変換}

入力信号が直流または直流に近い低周波ならば，チ ョッパ增幅器で增幅しガルバノメータを駆動させて記 録できる. 入力信号がペン書できない高い周波数であ る場合に，その信号が周期的ならば，低周波変換によ りペン書させることが可能でめる。

入力信号に含まれる周波数成分が直流から $f_{M}$ まで とすると，サンプリンダ定理年によって，(1）式で示 される時間間隔以内で入力信号をサンプリングしてゆ けば，波形を忠実に再現できる。

$$
\tau=1 / 2 f_{M}
$$

入力信号が周期的であり，その周期を $T_{i}$ として， サンプリング定理を応用すると，順次サンプリング時 点を $P T_{i}+\tau(P:$ 正の整数) ずつ遅らせてゆけば，入 力波形を保持したまま低周波変換することができ る.

このよらなサンプリングによる低周波変換方法をぺ ン書オシログラフに適用する場合の条件は，入力波形 を連続的泜低波変換できることである。サンプリン グ・オシロスコープのように入力波形の一部だけを時 間拡大して表示するサンプリング方式では，サンプリ ング・パルスを遅延させる方法に，きょ歯状波李たは 階段状波の電圧の大きさを利用しており，入力波形を 低周波変換させるためには，ペン書の波形を観測しな がら同期をとる必要があり，また，きょ歯状波（階段
状波）のフライバックによる波形の不連続な記録を防 ぐ補償回路が必要となるため，ペン書オシログラフへ の適用は一般にむずかしい。

本論文の方法を Fig. 1 に示す。サンプリング・パ
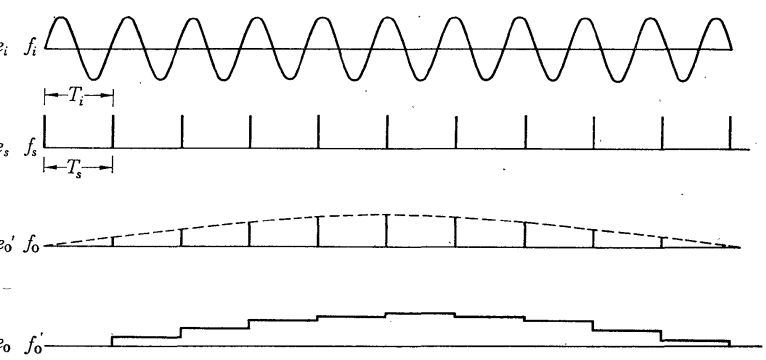

Fig. 1 Frequency conversion using sampling method $T_{i}=1 / f_{i}, T_{s}=1 / f_{s}$

ルス $e_{s}$ の繰返し周波数（以下サンプリング周波数と (ら)を $f_{s}$ とし, 繰返し周波数 $f_{i}$ （以下入力周波数 といら）の入力信号 $e_{i}$ を，その $P$ (正の整数）サイ クルごと火連続的にサンプリングして $e_{0}^{\prime}$ を得る.さ らにゼロ次ホールド回路によって出力 $e_{0}$ が得られる. ここで， $T_{s}>P \cdot T_{i}$ ならば，Fig.1 から明らかなよう にサンプリング・パルスは順次遅延していく。したが って，このサンプリング・パルス遅延方式（周波数差 方式という）では，従来の方式と異なり，同期叔よび フライバックの難点がないので連続して低周波変換す ることが可能であり，ただちにペン書し記録すること ができる.

周波数差方式のサンプリングによる周波数変換には， 時間的に順方向のサンプリングと逆方向のサンプリン グの 2 種類があり, 出力 $e_{0}$ の繰返し周波数 $f_{0}$ (以下 出力周波数という）は，次式で示される.

$$
f_{0}=\left|f_{i}-P \cdot f_{s}\right|
$$

(2) 式炕いて, Fig. 1 亿示す順方向のサンプリン グを行ならためには， $f_{i}-P \cdot f_{s}>0$ でなければならな い.この条件のもとで次式が得られる.

$$
f_{0}=f_{i}-P \cdot f_{s}
$$

（3）式に抒いて，出力周波数 $f_{0}$ をペン書可能な周波 数に固定して拈き, 入力周波数 $f_{i}$ の変化に応じてサ ンプリング周波数 $f_{s}$ を变化させれば，広帯域のペン 書きが可能になる。

入力信号 $e_{i}$ に含采れる周波数成分 $f_{m}$ 分，周波数 差方式のサンプリングにより低周波変換された出力 $e_{0}$ で再現されるためには，サンプリング定理から次式を 満足しなければならない。

$$
f_{m} \leq \frac{1}{2 \tau_{d}}
$$

ここで $\tau_{d}$ は，（1）式に相当するサンプリング時間 
間隔であり, 次式で示される.

$$
\tau_{d}=T_{s}-P \cdot T_{i}
$$

一般に $f_{m} \geq f_{i}>f_{0}$ であるから，(3)〜(5) 式から 次式が得られる.

$$
\frac{1}{2 P}\left(\frac{f_{i}}{f_{0}}-1\right) \geq \frac{f_{m}}{f_{i}}>1
$$

入力信号の基本波成分 $f_{i}$ が，低周波交換により $f_{0}$ と なるので，他の入力周波数成分 $f_{m}$ も同じ比率で低周 波変換される. これらの周波数成分が正確にペン書さ れるための条件は，下記のと括りである。ペン書オシ ログラフ固有の振幅特性で $3 \mathrm{~dB}$ 減衰する周波数を $F_{P}$ とするとペン書可能な入力周波数成分 $f_{m}$ は, 次式を 満足しなければならない。

$$
F_{P} \geq f_{m} \frac{f_{0}}{f_{i}}
$$

したがって，入力信号に含まれる周波数成分のらち， 振幅特性が $3 \mathrm{~dB}$ 以内の減衰でペン書される周波数成 分 $f_{m}$ は，(6)，(7) 式を同時に満足する範囲に制 限される. 一例として $F_{P} / f_{0}=8\left(F_{P}=80 \mathrm{~Hz}, f_{0}=\right.$ $10 \mathrm{~Hz})$ とした場合， $3 \mathrm{~dB}$ 以内の減衰でペン書される 周波数範囲は, Fig. 2 の斜線の領域である.上記のこ

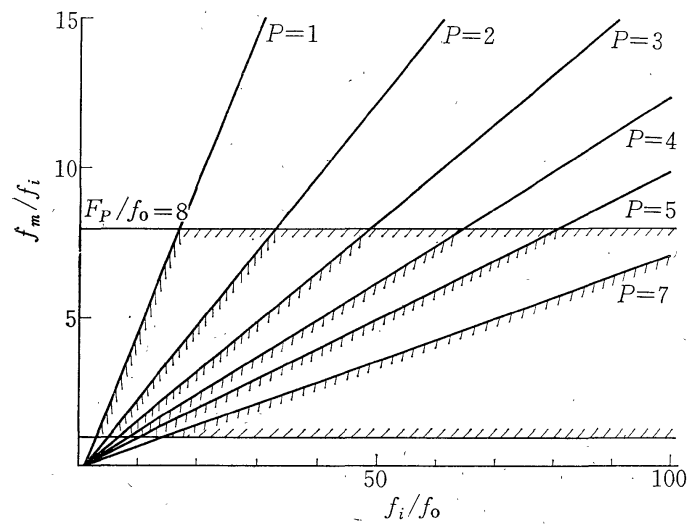

Fig. 2 Frequency band of output signal とから，入力波形を忠実にペン書きするためには， $P=1$ とし， $F_{P} / f_{0}$ 㧊よび $f_{i} / f_{0}$ の值を大きくするこ と，すなわ台 $f_{0}$ を低くす机ばよいことがわかる.

サンプリングによる高調波は, 次のようにして求め られる，入力を，余弦波とすると，ゼロ次ホールド回 路の出力電圧 $e_{0}$ は, 次式で表わされる5).

$$
\begin{aligned}
\bar{e}_{0}(t)= & \sum_{n=-\infty}^{\infty} \frac{1}{2}\left\{\frac{\sin \pi\left(f_{0} / f_{s}-n\right)}{\pi\left(f_{0} / f_{s}-n\right)} \cos 2 \pi\left(n f_{s}-f_{0}\right)\right. \\
& \left.+\frac{\sin \pi\left(f_{0} / f_{s}+n\right)}{\pi\left(f_{0} / f_{s}+n\right)} \cos 2 \pi\left(n f_{s}+f_{0}\right)\right\}
\end{aligned}
$$

（8）式から，サンプリングによる高調波成分の影響 を少なくするためには， $f_{0} / f_{s}$ を小さくすること，す なわち出力周波数 $f_{0}$ を低くすることである.

\section{$2 \cdot 2$ 周波数制御}

入力周波数やサンプリング周波数には, 温度変化や 電源電圧変動などによる周波数変動が存在する．入力 周波数の变動を $\Delta f_{i}$, 出力叔よびサンプリング周波数 のドリフトをそれぞれ $\Delta f_{0}, \Delta f_{s}$ とすると（3）式か ら次式が得られる。

$$
\Delta f_{0}=\Delta f_{i}-P \Delta f_{s}
$$

(9) 式を $f_{0}$ で正規化すると次式が得られる.

$$
\frac{\Delta f_{0}}{f_{0}}=\frac{\Delta f_{i}}{f_{i}} \frac{f_{i}}{f_{0}}-P \frac{\Delta f_{s}}{f_{s}} \frac{f_{s}}{f_{0}}
$$

入力周波数変動 $\Delta f_{i} / f_{i}$ 叔よびサンプリング周波数ド リフト $\Delta f_{s} / f_{s}$ の值が小さくとも， $f_{i} / f_{0}, f_{s} / f_{0}$ は一般 に大きな值なので, (10) 式から. $\Delta f_{0} \mid f_{0}$ の值は大きく なり，そのままでは測定に支障をきたし，広带域化の さをたげとなる。

出力周波数のドリフト $\Delta f_{0}$ の補償を行なら周波数 制御系を Fig. 3 飞示す. ここで, $P$ は, $(9)$ 式の $P$

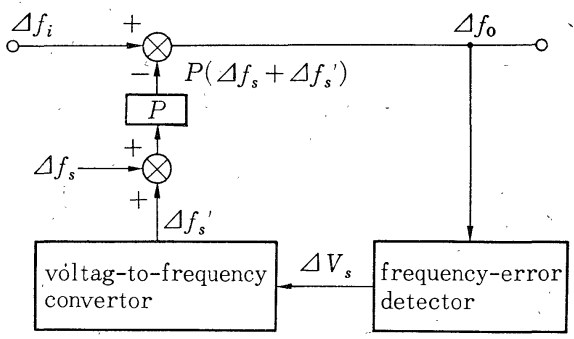

Fig. 3 Sampling frequency control system

に相当する. Fig. 3 で, 出力周波数 $f_{0}$ に設定值 $F_{0}$ をもうけ，設定值 $F_{0}$ からのずれ $\Delta f_{0}$ を検出し，電圧 一周波数変換回路の発振周波数（サンプリング周波数） を変化させ $\Delta f_{0}$ を補償する。

電圧一周波数変換回路として Fig. 4 亿示す回路を用 いた. この回路の 発振周波数 $f_{s}$ は, 次式で示され $ろ^{6)}$.

$$
f_{s}=\frac{\alpha\left(V_{s}-V_{b e}\right)}{2 C R_{B} V_{E}}
$$

ここで $\alpha$ は, $\mathrm{T}_{5}, \mathrm{~T}_{6}$ の共通ベース接地の電流増幅度, $V_{b e}$ は $\mathrm{T}_{5}, \mathrm{~T}_{6}$ のベース・エミッタ間電圧である. ま た，ダイオード $\mathrm{D}_{1}, \mathrm{D}_{2}$ は，サンプリング周波数 $f_{s}$ を安定化するため温度補償に用いた。

周波数誤差検出回路は, 設定值 $F_{0}$ からの微少周波 数差 $4 f_{0}$ を感度良く検出する必要があり, Fig. 5 に 示す回路を考案したすすなわち，こう配の急峻なフィ ルタで周波数の微小変化を大きな振幅变化に変換し整 流した. Fig. 5 のフィルタ 1，2 の極周波数をそれぞ れ $F_{1}(9.0 \mathrm{~Hz}) ， F_{2}(11.0 \mathrm{~Hz})$ としたときの周波数誤 差検出特性ば, Fig. 6 亿示される. この回路の設定值 $F_{0}$ 付近の線形部分での伝達関数 $G_{D}(s)$ は, 次のよう 


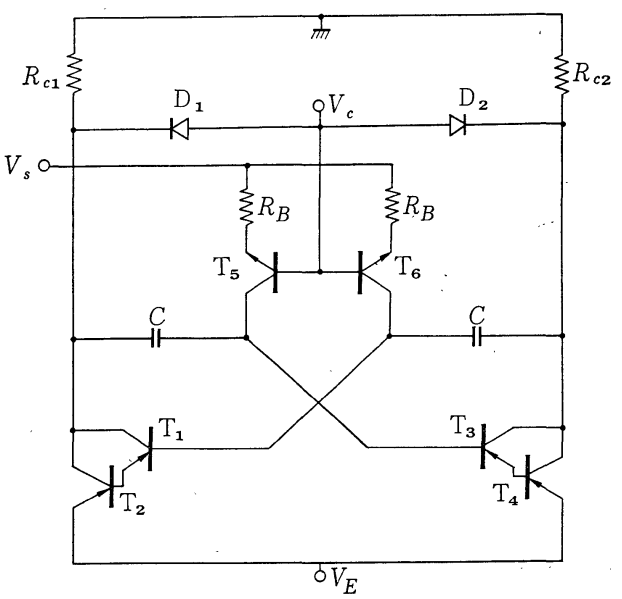

Fig. 4 Voltage-to-frequency converter (astable multivibrator with constant-current sources) に表わされる (付録参照).

$$
G_{D}(s)=\frac{\Delta V_{s}}{\Delta f_{0}}=A \frac{1+s\left(T+T^{\prime}\right) / 2}{(1+s T)\left(1+s T^{\prime}\right)} e^{-s T_{0}}
$$

ここで $A$ は, 周波数誤差検出感度, $T_{0}$ は, 出力周期 の設定值であり $T_{0}=1 / F_{0}, T, T^{\prime}$ は次式で示される.

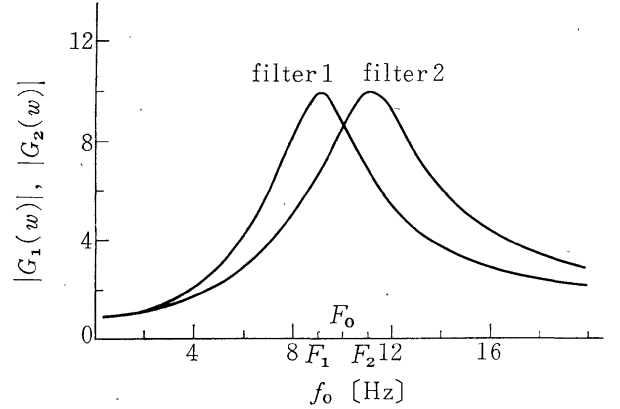

(a)

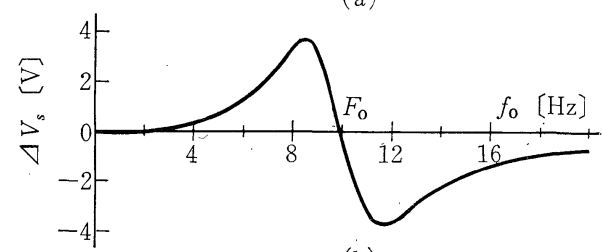

(b)

Fig. 6 Characteristic of filter and frequency-error detector under the condition of $F_{0}=10.0 \mathrm{~Hz}$, $F_{1}=9.0 \mathrm{~Hz}, F_{2}=11.0 \mathrm{~Hz}, A_{F}=10.0, A_{d}=1$, $n=1$

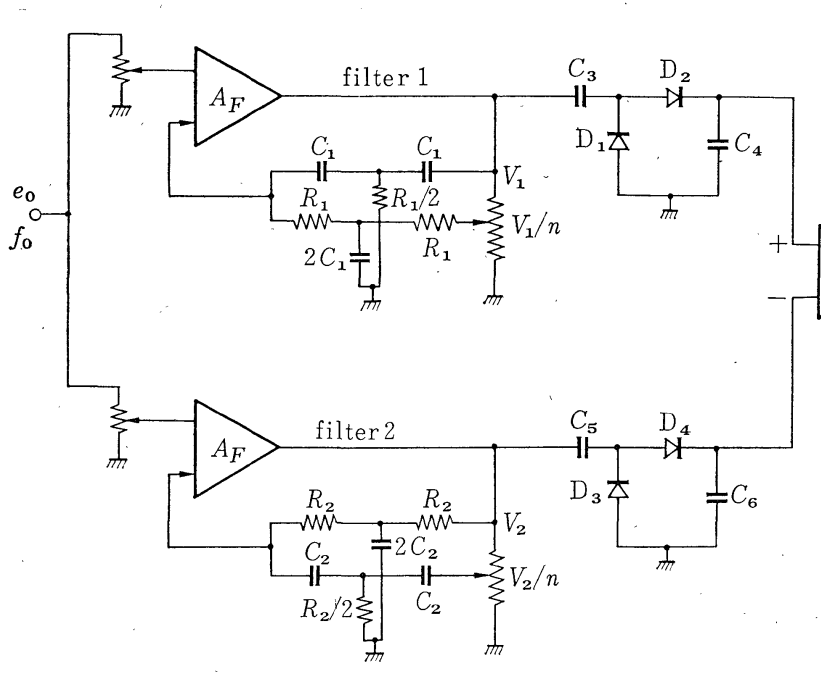

Fig. 5 Frequency-error detector

$$
\begin{aligned}
& T=T_{0} / \log \left(1+\frac{C_{3}}{C_{4}}\right) \\
& T^{\prime}=C_{4} \frac{R_{i} R_{r}}{R_{i}+R_{r}}
\end{aligned}
$$

$R_{i}$ は, 差動増幅器 $A_{d}$ の入力インピーダンス, $R_{r}$ は ダイオード $\mathrm{D}_{2}\left(\mathrm{D}_{4}\right)$ の逆バイアス時の抵抗であり, $C_{3}$ $=C_{5}, C_{4}=C_{6}$ とした.

Fig. 3 に和いて, 周波数誤差検出回路の出力電圧 $\Delta V_{s}$ により制御されるサンプリング周波数を $\Delta f_{s}^{\prime}$ と すると，（9），(11)，(12）式から次式が得られる.

$$
\left\{\begin{array}{l}
\Delta f_{0}=\Delta f_{i}-P \cdot\left(\Delta f_{s}+\Delta f_{s}{ }^{\prime}\right) \\
\Delta f_{s}^{\prime}=B \cdot \Delta V_{s} \\
\Delta V_{s}=G_{D}(s) \Delta f_{0}
\end{array}\right.
$$

ここで $B$ は, 電圧-周波数変 換係数であり，(11) 式から $B$ $=\alpha /\left(2 C R_{B} V_{E}\right)$ である. (15) 式を $\Delta f_{0}$ について解くと次式 が得られる.

$\Delta f_{0}=$

$$
\frac{\Delta f_{i}-P \cdot \Delta f_{s}}{1+P \cdot A \cdot B \frac{1+s\left(T+T^{\prime}\right) / 2}{(1+s T)\left(1+s T^{\prime}\right)} \cdot e^{-s T_{0}}}
$$

ここで $P \cdot A \cdot B$ は，周波数制御 系のループ利得であり, この值 を大きくすることにより，周波 数ドリフト $\Delta f_{0}$ を小さくする。

ことができる。

\section{3. 広帯域化チョッパ増幅器}

\section{$3 \cdot 1$ チョッパ増幅器への適用}

ペン書オシログラフは, 一般に入力信号増幅用とし てチョッパ増幅器を内藏しておゔ, これに2. で述べ た低周波変換方式を適用し広帯域化をはがる。

高速ペン書オシログラフでは, チョッパに半導体 (トランジスタ，FET ダイオード）を用いる場合が多 い.この変調チョッパを幅の狭いパルスで駆動すれば, 
サンプリングも行なうことができる。また，サンプリ ング後, 波形を再現させるためには, チョッパ増幅器 の復調部をゼロ次ホールド回路に置きかえればよい. さらに半導体チョッパ駆動用に Fig. 4 の電圧-周波数 変換回路を用い，入力周波数 $f_{i}$ に応じて，Fig. 4 の 制御電圧 $V_{s}$ を変化させれば，出力設定周波数を得る ことができる.

上記の方法により，1個のチョッパ増幅器で直流や それに近い超低周波信号の増幅と高周波信号の低周波 変換が可能になる. このチョッパ增幅器は, 変調, 復 調チョッパが同相で動作するだめ, サンプリング時に 峈いても多量の帰還ががられ，ゲイン特性の改善や 雑音の低減がはかられる7).

さらに，ホールド回路をもつ ため, チョッパ動作時のサグ を減少できる利点もある ${ }^{8)}$.

チョッパ増幅器にサンプリ ング機能をもたせた場合に， チョッパ駆動パルスの幅が狭 いことと，繰返し周波数が高 いことから, 半導体チョッパ のスパイクによる動的オフセ ット電圧や動的ドリフトが増 大するという久点がある。卜

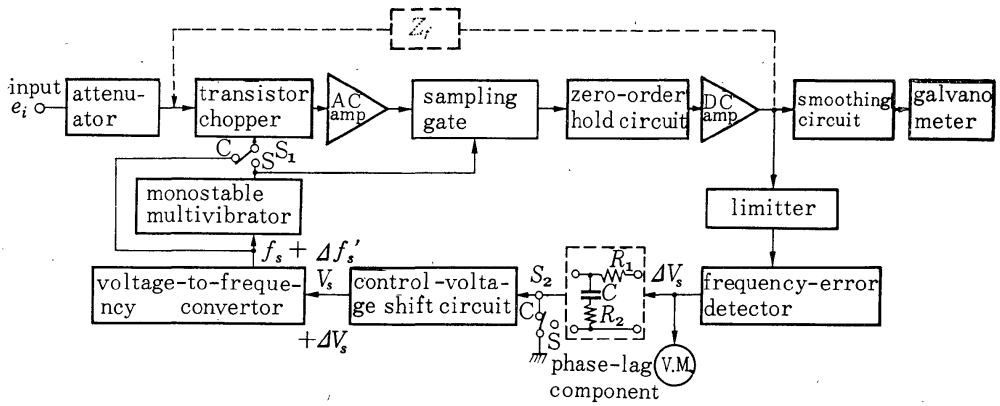

Fig. 7 Block diagram of the chopper amplifier with sampling operation

ランジスタ・チョッパでは，キャリア蓄積効果による スパイクが発生しオフセット電圧の原因となる. チョ ッパ駆動周波数を $f_{S}$ としたとき，チョッパ入力概算 オフセット電圧 $\theta_{d}$ は, 次式で示される ${ }^{9)}$.

$$
\theta_{d}=2 f_{s}\left(s_{A}+s_{B}\right)
$$

ここで $s_{A}, s_{B}$ は，それぞれトランジスタのオン,才 フ時に発生するスパイクの面積である. (17) 式のオ フセット電圧 $\theta_{d}$ によりサンプリング周波数 $f_{s}$ の上 限が定まり，乙たがって低周波変換できる入力周波数 の上限も決定される.

\section{$3 \cdot 2$ 回路 構成}

ペン書オシログラフの広帯域化に用いるチョッパ増 幅器の回路構成 ${ }^{10)}$ を Fig. 7 に示す. これをチョッパ 増幅器として用いる場合は, スイッチ $\mathrm{S}_{1}, \mathrm{~S}_{2}$ を $\mathrm{C}$ 側 にする. そして制御電圧シフト回路の出力電圧 $V_{S}$ に よって, 電圧-周波数変換器の発振周波数を $1 \mathrm{kHz}$ に 調整し, 変調チョッパ（トランジスタ・チョッパ）と 復調チョッパ(サンプリング・ゲート)を駆動する．復 調された信号電圧は, ゼロ次ホール回路で波形が再現 され, さらに電力増幅されガルバノメータを駆動する.

いっぽう，ペン書できない高周波の繰返し信号を低 周波に変換する場合は，まずスイッチ $\mathrm{S}_{1}$ を $\mathrm{S}$ 側に，
$\mathrm{S}_{2}$ をC 側にする。そうするとチョッパは単安定マル チバイブレータの幅の狭い出力パルスで駆動され，入 力電圧 $e_{i}$ をサンプリングする，サンプリングされた 信号は，増幅された後，サンプリング・ゲート打よび ホールド回路で復調される.さらに直流増幅回路で増 幅された出力電圧の一部は,リミッタで振幅を一定に され周波数誤差検出回路にはいる.つぎに Fig. 7 の 電圧計 V. M. の指示がゼロとなるようと制御電圧シ フト回路の出力電圧 $V_{s}$ を調整する。 こ机により出力 周波数 $f_{0}$ は, 設定值 $F_{0}$ に等しくなる. ここでスイ ッチ $\mathrm{S}_{2}$ を $\mathrm{S}$ 側にすると, Fig. 3 に示した周波数制 御系が動作し, 出力周波数 $f_{0}$ は, 設定值に固定され
ペン書が可能となる.
ここで考慮すべきことは, $f_{0}=P f_{s}-f_{i}$ でも, 出力 周波数 $f_{0}$ が設定值 $F_{0}$ に等しくなり， Fig. 7 の. M. の指示をゼロとすることである. これは逆方向の サンプリングであり, 周波数制御系を閉じると正帰還 がかかり周波数ドリフトの補償ができない。また, 任 意の $P$ でも Fig. 7 の V. M. の指示はゼロとなるが, (16) 式に示される周波数制御系のループ利得 $P A B$ の值も変わる. この制御系は, むだ時間を含むため系 を安定にして括くために $P A B$ の值に上限がある. し たがって，P を任意の值とするとループ利得が変わっ て，系が不安定になる場合も生ずる。

上記のことを避けるために， $P=1$ とする。これは， Fig. 2 からも妥当な值である. さらに入力周波数に上 限 $F_{i M}$ をもらける． $F_{i M}$ は变調チョッパのオフセッ 卜電圧から決定される. そこでサンプリング周波数 $f_{s}$ に（3）式から, 次式で示される調整範囲をもらける.

$$
\frac{\left(F_{i M}-F_{0}\right)}{2^{n+1}}<f_{s} \leq \frac{F_{i M}-F_{0}}{2^{n}} \quad n=0,1,2, \cdots
$$

ここで， $F_{0}$ は出力設定周波数である. サンプリング 周波数 $f_{s}$ を設定する場合は，まず (18) 式で $n=0$ と し, サンプリング周波数 $f_{s}$ を $\left(F_{i M}-F_{0}\right) / 2$ から $F_{i M}$ 
- $F_{0}$ まで順次高くしてゆき，Fig. 7 の V.M. の指示 をゼロとするサンプリング周波数をさがす．この範囲 になければ， $n=1$ とし再び上記と同様の操作を行な い順次 $n$ を増していく：このようにして Fig.7 のV. M. の指示がゼ口となったとき，出力周波数 $f_{0}$ は， $P=1$ の順方向のサンプリングにより設定值 $F_{0}$ に等 しくなる.このときのサンプリング周波数 $f_{s}$ は (11) されるので, 入力周波数 $f_{i}$ は, (3) 式より次式で示 される.

$$
f_{i}=f_{s}+F_{0}
$$

Fig. 7 の上端の点線は電圧帰還で, また位相遅れ要 素は周波数制御系を安定化するためにそら入した。

\section{3 試作回路の特性}

Fig. 7 亿示した回路の試作を行なった. 変調チョッ パには，チョッパ用トランジスタ $2 \mathrm{~N} 2162$ ，サンプリ ジ形ゲートを使用した。電圧一周波数変換器は, -0.5 $\mathrm{V}$ から $-12 \mathrm{~V}$ の制御電圧 $V_{s}$ に対し, $50 \mathrm{~Hz}$ から 1.2 $\mathrm{kHz}$ まで線形に変化した. 周波数誤差検出回路の特性 は，Fig. 6 に示した特性之同等である.出力周波数の 式より電圧一周波数変換回路の制御電圧 $V_{s}$ から算出 ング・グートには，ダイオード1S 73 を用いたブリッ

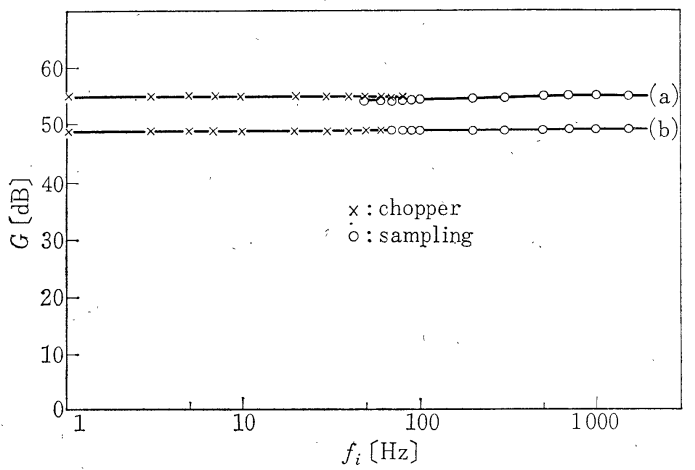

Fig. 9 Gain characteristic of the chopper amplifier

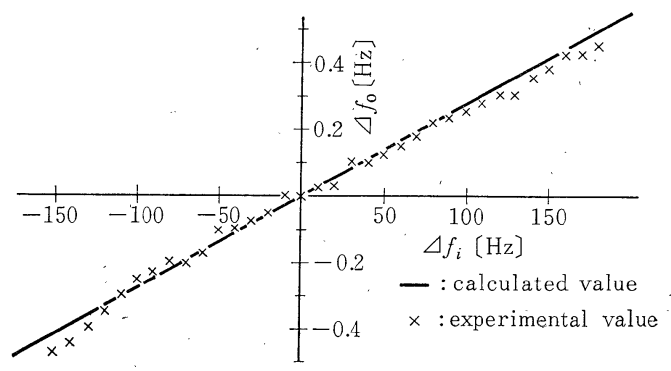

Fig. 10 Frequency drift under the condition of $F_{i}=700 \mathrm{~Hz}, F_{0}=10 \mathrm{~Hz}, A B=356$

設定值 $F_{0}$ を $10.0 \mathrm{~Hz}$ に, 入力周波数 の上限 $F_{i M}$ を $1.1 \mathrm{kHz}$ にした.

試作回路で繰返乙周波数 $1 \mathrm{kHz}$ の各 種入力波形を $10 \mathrm{~Hz}$ 飞低周波変換し てペン書させた結果の一例を Fig. 8 に示す。この図から連続的な低周波変 換がなされていることがわかる。また， これらの波形から基本波成分 $1 \mathrm{kHz}$ に対し,十数 $\mathrm{kHz}$ の高調波成分まで十 分ペン書されていることが推定できる。

電圧利得特性を Fig. 9 亿示す。この 図で (a) 線は, $80 \mathrm{~Hz}$ 付近で電圧利得

Fig. 8 Output waveforms
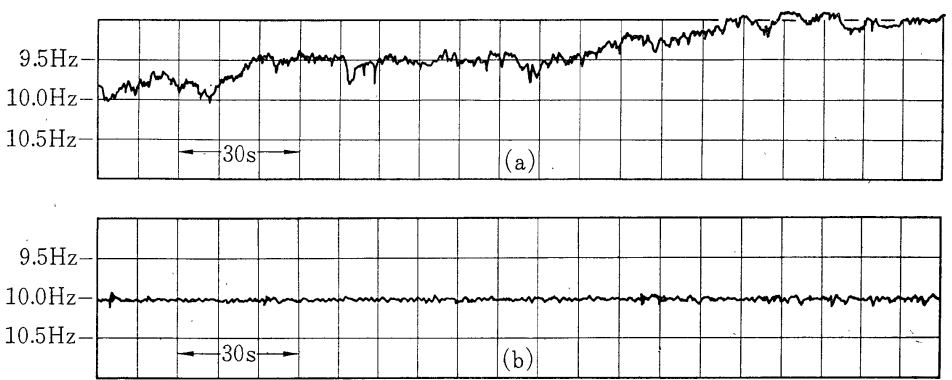

Fig. 11 Frequency drift of the output signal (a) uncompensated (b) compensated
が減少しているが，電圧帰還量を 增すことにより (b) 線のようにチ ョッパ動作, サンプリング動作に かかわらず平担な特性が得られた。

周波数制御系の静特性の一例を Fig. 10 に示す. ここで入力周波 数は $700 \mathrm{~Hz}$ であるが，他の值の ときも同様な結果が得られている. Fig.11 に出力周波数ドリフト $\Delta f_{0}$ を周波数誤差検出回路で電压に変 換して示した.ここで（a）は周 
波数制御しない場合，（b）は周波数制御を行なった 場合の結果である。この図から，周波数制御系によっ て出力周波数のドリフト $\Delta f_{0}$ は $\pm 0.1 \mathrm{~Hz}$ 以内（設 定值 $10 \mathrm{~Hz}$ に対し $\pm 1 \%$ ）飞抑えられていることが わかる。この測定に用いた入力信号は，ウィンブリッ ジ形発振器の出力であり, $f_{i}=1 \mathrm{kHz}$ である.

\section{4. あとがき}

本論交で述べた新しいサンプリング・パルス遅延方 式（周波数差方式）のサンプリングによって同期操作 なしに入力波形を連続して低周波変換することができ た.この周波数差方式のサンプリングは，チョッパ増 幅特性をとこならことなしに，チョッパ増幅器に容易 に適用することができる。ささらに，電圧带還をかける ことにより，チョッパ動作执よびサンプリング動作時 の電圧利得特性を平担にすることができる。したがっ て, このチョッパ增幅器をペン書オシログラフに用い ると直流から高周波までの広帯域のペン書ができる.

試作回路では, 繰返乙周波数 $70 \mathrm{~Hz}$ から $1.2 \mathrm{kHz}$ までの信号を $10 \mathrm{~Hz}$ に低周波変換することができた. また，使用したペン書オシログラフの振幅特性で $3 \mathrm{~dB}$ 減衰する周波数 $F_{P}$ は $80 \mathrm{~Hz}$ であったが, Fig. 8 亿 示したように基本波成分 $1 \mathrm{kHz}$ の信号では, 十数 $\mathrm{kHz}$ の周波数成分までペン書できた。これは従来のペン書 オシログラフでは考觉られない值である. 変調チョッ パや電圧-周波数変換回路の変換特性を改善すれば, さらに広帯域化できるであるら。

広帯域化のさまたげとなる出力周波数ドリフトは, 本論文で考案した周波数制御系で（16）式に示される ように低減できる，この制御系は，周波数の変化が遅 いほど効果的である。一般に入力周波数の変動やサン
プリング周波数のドリフトの変化は遅く, Fig. 11 に 示したように出力周波数ドリフトを十分低減すること ができた.

サンプリング周波数の調整は, Fig. 7 の V.M. の 指示がゼロとなるようにすればよく，そのさいペン書 させる必要がないので便利である，さらに，サンプリ ング周波数の自動設定，括よび周波数制御系の安定化 の問題があるが，これらは別の機会に述べたい．

終わりに本研究の実験に協力していただきました本 学西山和義技官 (現在, コロンビア電子), 本学学生田 中 隆君(現在，東芝アンペックス)，拈よびいろいる 助言を与えていただきむした本学西塚典生助教授, 高 梨良一, 服部正行助手に梁謝致します。

\section{参 考 文 献}

1）関 英男：シンクロスコープ, 106/120, 日刊工業新聞社 (1965)

2) Millman \& Taub : Pulse Digital and Switching Waveforms, 627/667, McGraw-Hill

3）田宮・川又：パルス回路の設計マニアル，457/492，丸 善 (1968)

4）大泉添か：情報理論，70/72，オ一ム社（1968）

5） 半導体ハンドブック編集委員会: 半導体ハンドブック, 653/658, オーム社 (1963)

6) B. D. Rakovich \& S. Tesic : Voltage-to-Frequericy Conversion, Electronic Engineering, 39-478, 766/ 768 (1967)

7）渡部・中津山：チョッパ增幅器の負㷌還量の限界につ Wて, 電気四学会連合大会講演論文集, 2044 (1969)

8）中津山：ホールド回路をもつチョッパ增幅器, 電気学 会誌, 83-892 51/55 (1963)

9）田宮・川又：直流增幅器の設計マニアル，480/492，丸 善 (1968)

10）渡部・中津山：サンプリソグ機能をもつチョッパ增幅 器, 電気関倸学会東北交部連合大会講演論文集, $3 \mathrm{C}-21$ (1969)

\section{【周波数誤差検出回路の伝達関数 $\boldsymbol{G}_{\boldsymbol{D}}(\boldsymbol{s})$ の計}

算】 Fig. 5 の周波数誤差検出回路の入力信号 $e_{0}$ の 振幅は，Fig.7のりミッによって二定になっ.てい る. 亿たがってこの回路の設定值 $F_{0}$ 付近の線形部 分 (Fig. 6(b) 参照) の伝達関数 $G_{D}(S)$ は，微小周 波数变化 $\Delta f_{0}=f_{0}-F_{0}$ に対する検出回路の出力電圧 $\Delta V_{s}$ によって次のように定義する.

$$
G_{D}(S)=\frac{\Delta V_{s}}{\Delta f_{0}}
$$

Fig. 5 のバンドパス・フィルタ 1, 2 の伝達関数は, それぞれ次式で表わされる。

$$
G_{1}(S)=A_{F} \frac{S^{2} C_{1}{ }^{2} R_{1}{ }^{2}+S 4 C_{1} R_{1}+1}{S^{2}\left(1+A_{F}\right) C_{1}{ }^{2} R^{2}+S 4 C_{1} R_{1}+\left(1+\frac{A_{F}}{n}\right)}
$$




$$
G_{2}(S)=A_{F} \frac{S^{2} C_{2}{ }^{2} R_{2}{ }^{2}+S 4 C_{2} R_{2}+1}{S^{2}\left(1+\frac{A_{F}}{n}\right) C_{2}{ }^{2} R_{2}{ }^{2}+S 4 C_{2} R_{2}+\left(1+A_{F}\right)}
$$

ここで抵抗減衰器の分圧比 $n$ は, 以下の条件で決まる. サンプリング周波数調整時には, 出力周波数の設定值 $F_{0}$ に対し, 入力周波数 $f_{0}$ が, $f_{0} \gg F_{0}$, “敊よび $f_{0} \ll F_{0}$ 飞扮いて Fig. 7 の V.M. の指示をゼ口としないよう に $n>1$ とする. 周波数ドリフト補償時には, 検出感 度を上げるため $n=1$ とする，ここでは，後者をとる。

検出回路の入力電圧 $e_{0}$ は，多くの周波数成分を含 んでいるが，フィルタは狭帯域通過特性となっている ので高調波成分は減衰してしまう，したがって基本波 成分（この場合は出力周波数 $f_{0}$ ) の及考えればよい.

一般にフィルタの過渡状態は, 整流回路のそれに比 らべ短時間に終了するから，フィルタの過渡状態を無 視できる. また, 出力周波数 $f_{0}$ は, 設定值 $F_{0}$ 火近 い值であからフィルタの出力は, 単一正弦波（周波数 は $\left.F_{0}\right)$ として扱らことができる. したがってフィル 夕については，(A·2)，(A.3) 式から微少周波数変動 $\Delta f_{0}$ に対する振幅の変化だけを考光ればよい，

Fig. 5 の整流回路のコンデンサ $C_{3}, C_{4}, C_{5}, C_{6}$ の充 電は，正弦波の正和よび負のピーク值によるから，

Fig. A (a) 亿示す方形波で近似する. 正のピーク值の

(a)

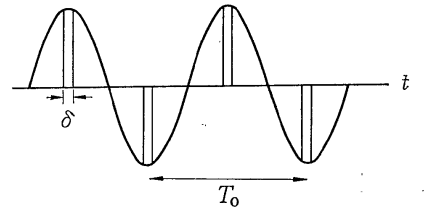

(b)

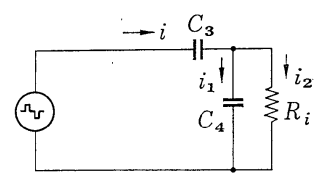

Fig. A Rectifying circuit (a) input waveform of the rectifying circuit (b) equivalent circuit

ときの整流回路の等価回路を Fig. A (b) そ示す. この 図で次式が成立する。

$$
\left\{\begin{array}{l}
\frac{i}{S C_{3}}-\frac{V_{3}^{n}}{S}+\frac{i_{1}}{S C_{4}}+\frac{V_{4}^{n}}{S}=\frac{V_{0}^{n+1}}{S} \\
i_{2} R_{i}=\frac{i_{1}}{S C_{4}}+\frac{V_{4}^{n+1}}{S} \\
i=i_{1}+i_{2}
\end{array}\right.
$$

ここで $R_{i}$ は, Fig. 5 の差動増幅器 $A_{d}$ の入力抵抗 であり， $V_{0}{ }^{n}, V_{3}{ }^{n}, V_{4}{ }^{n}$ はそれぞれ, 周波数 $f_{0}$ が変 化してからnサイクル目の $e_{0}$ の正のピーク值，特よ
び $C_{3}, C_{4}$ の端子電圧である. (A.4) 式を $C_{4}$ の端子 電圧について解き $V_{4}{ }^{n+1}$ と沶くと次の漸化式が得ら れる。

$$
\begin{aligned}
V_{4}^{n+1}= & \left\{\frac{C_{3}}{C_{3}+C_{4}}\left(V_{0}^{n+1}+V_{3}^{n}\right)\right. \\
& \left.+\frac{C_{4}}{C_{3}+C_{4}} V_{4}^{n}\right\} e^{-\left(\hat{\delta} / R_{i}\left(C_{3}+C_{4}\right)\right)} e^{-\left(T-\hat{o} / R C_{4}\right)}
\end{aligned}
$$

$$
R=\frac{R_{i} R_{r}}{R_{i}+R_{r}} \quad n=0,1,2, \cdots \cdots
$$

$R_{r}$ はダイオード $\mathrm{D}_{2}\left(\mathrm{D}_{4}\right)$ の逆バイアス抵抗である. また $V_{3}^{n}$ は，周波数 $f_{0}$ が変化してから $n$ 乎イクル目 の $e_{0}$ の負のピーク值として与兄られる.

この整流回路は，正のピーク值がこないと出力電圧 に変化が現われないので, 出力周期 $T_{0}=1 / F_{0}$ だけの むだ時間が存在する（A.5) 式から次式が得られる.

$$
\left\{\begin{array}{l}
\Delta V_{1}(t)=2 b_{1} D_{1} \Delta f_{0}\left(1-e^{-\left(\left(t-T_{0}\right) / T\right)}\right) U\left(t-T_{0}\right) \\
T=T_{0} / \log \left(1+\frac{C_{3}}{C_{4}}+\frac{\delta}{R_{i}\left(C_{3}+C_{4}\right)}+\frac{T_{0}-\delta}{R C_{4}}\right) \\
b_{1}=\frac{\left|G_{1}(\omega)\right|-\left|G_{1}\left(\omega_{0}\right)\right|}{\Delta f_{0}} \quad(\mathrm{~A} \cdot 6) \\
D_{1}=\frac{C_{3} e^{\left(-\delta / R i\left(C_{3}+C_{4}\right)\right)} e^{-\left(\left(T_{0}-\delta\right) / R C_{4}\right)}}{C_{3}+C_{4}\left(1-e^{-\left(\delta / R_{i}\left(C_{3}+C_{4}\right)\right)} e^{-\left(\left(T_{0}-\delta\right) / R C_{4}\right)}\right)} \\
\omega=2 \pi f_{0} \\
\omega_{0}=2 \pi F_{0}
\end{array}\right.
$$

ここで $t=n T_{0}, \Delta V_{1}(t)=V_{4}^{n}$ とし，U(t) は単位ステ ップ関数である.

いっぽう，入力電圧が $C_{4}$ の端子電圧より低くなる 場合は $C_{4}$ の電荷は， $R_{i}$ 和よび $R_{r}$ を通し放電する から, 出力電圧 $V_{1}(t)$ は, 次のようになる.

$$
\begin{aligned}
& \Delta V_{1}(t)=2 b_{1} \Delta f_{0}\left(1-e^{-\left(t / T^{\prime}\right)}\right) \\
& T^{\prime}=C_{4} \frac{R_{i} R_{r}}{R_{i}+R_{r}}
\end{aligned}
$$

$C_{6}$ の端子電压についても同様であり，(A・6), (A. 7) 式で $C_{3}=C_{5}, C_{4}=C_{6}$ 拉よび添字 1 を 2 にすればよ い.

(A.6) 式で $\delta \ll R_{i}\left(C_{3}+C_{4}\right), T_{0} \ll R C_{4}$ 抢よび $b_{1}=$ $b_{2} \equiv b$ である. また $C_{3}=C_{5}, C_{4}=C_{6}$ とすると設定周 波数付近では, $C_{4}, C_{6}$ の充・放電は差動的汇行なわれ るから, 検出回路の伝達関数 $G_{D}(S)$ は, 次のように 書くことができる.

$$
G_{D}(S)=A \frac{1+S\left(T+T^{\prime}\right) / 2}{\left(1+S T^{\prime}\right)(1+S T)} e^{-S T_{0}}, \quad A=4 A_{d} b
$$

